\title{
Model Latihan Dayung Berbasis Modifikasi Alat Untuk Atlet Pemula
}

\author{
Deden Akbar Izzuddin', Qorry Armen Gemael² \\ ${ }^{1}$ Universitas Singaperbangsa Karawang, Ilmu Keolahragaan, Karawang, \\ Indonesia \\ ${ }^{2}$ Universitas Singaperbangsa Karawang, Ilmu Keolahragaan, Karawang, \\ Indonesia \\ Deden.akbar@fikes.unsika.ac.id, gorry.gemael@fikes.unsika.ac.id
}

\begin{abstract}
This study focuses on whether the development of a Canoeing modified based exercise model for novice athletes provides the effectiveness of improving canoeing skills in canoeing sports. Research method used in this research is Research method of development Research \& Development ( $R$ \& D). This research was conducted on UKM Dayung Singaperbangsa. Using research design or research steps are: (1) Research and information collecting; (2) Planning; (3) Development of the preliminary from of product; (4) Preliminary field testing; (5) Main product revision (6) Main field test; (7) Operational product revision; (8) Operational field testing; (9) Final product; (10) Dissemination and implementation. Based on the research results obtained pretest average value is 53.95 and average posttest value is 75.75 .
\end{abstract}

Key words :Canoeing Exercise, Modification

\section{Abstrak}

Penelitian ini berfokus pada apakah pengembangan model latihan dayung berbasis modifikasi alat untuk atlet pemula memberikan keefektifan untuk meningkatkan keterampilan dayung pada olahraga dayung. Metode Penelitian yang digunakan dalam penelitian ini adalah metode Penelitian pengembangan Research \& Development $(R \& D)$. Penelitian ini dilaksanakan pada UKM Dayung Singaperbangsa. Dengan menggunakan desain penelitian atau langkah-langkah penelitian yaitu: (1)Research and information collecting; (2) Planning; (3)Development of the preliminary from of product; (4) Preliminary field testing; (5) Main product revision (6) Main field test; (7) Operational product revision; (8) Operational field testing; (9)Final produk; (10) Dissemination and implementation. Berdasarkan hasil penelitian didapat nilairata-rata pretest 53,95 dan nilai ratarata posttest 75,75 .

Kata kunci :Latihan Dayung, Modifikasi

\section{PENDAHULUAN}

Dayung merupakan olahraga yang menggunakan alat berupa perahu dan dayungan. Teknik dasar mendayung sangat berpengaruh dalam mencapai sebuah prestasi karena seorang pendayung harus mampu mendayung sambil 
mempertahankan keseimbangan supaya laju perahu cepat dan tidak terjatuh.

Sarana dan prasarana yang kurang memadai mengakibatkan latihan kurang efektif. Waktu latihan menggunakan perahu pun sangat sedikit dengan jumlah atlet yang cukup banyak. Tujuan dari latihan tidak tercapai. Maka perlu adanya model latihan untuk mengatasi permasalahan tersebut.

Pemilihan model latihan yang digunakan dalam melatih keterampilan dalam olahraga dayung harus tepat karena dalam olahraga dayung peningkatan keterampilan dayung sangat penting. Model harus benar-benar melatih keterampilan mendayung yang diperlukan dalam olahraga dayung. Model latihan yang dapat diberikan untuk melatih keterampilan mendayung dalam olahraga dayung yaitu model latihan dayung berbasis modifikasi alat untuk atlet pemula.

Model latihan dayung berbasis modifikasi alat untuk atlet pemula merupakan modifikasi latihan dayung yang dilakukan di daratan. Pendayung melakukan proses latihan untuk menguasai dan meningkatkan keterampilan mendayung dengan memanfaatkan alat yang sederhana. Modifikasi alat untuk atlet pemula yang digunakan berupa tali, tongkat, karet dan bola pendayung dapat latihan mendayung seperti halnya latihan di atas perahu. Model latihan berbasis modifikasi alat untuk atlet pemula ini tidak hanya melatih keterampilan mendayung saja tetapi melatih kekuatan, daya tahan stability, dan meningkatkan koordinasi otot saraf.

Model dapat dikatakan sebagai sesuatu yang menggambarkan adanya pola berpikir. Sebuah model menggambarkan keseluruhan konsep yang saling berkaitan. Sugiyono (2013:297) mengatakan bahwa "metode penelitian dan pengembangan atau dalam bahasa inggrisnya Research \& Development adalah metode penelitian yang digunakan untuk menghasilkan produk tertentu, dan menguji keefektifan produk tersebut".

Secara umum istilah model diartikan sebagai kerangka konseptual yang digunakan sebagai pedoman atau acuan dalam melakukan kegiatan. Model juga diartikan sebagai barang atau benda tiruan dari benda sesungguhnya, misalnya miniatur tugu monas yang dipakai sebagai gambaran tugu monas sebenarnya. model digunakan untuk menunjukkan pengertian pertama sebagai kerangka proses pemikiran. Model dasar dipakai untuk menujukkan model yang generik yang berarti umum dan mendasar yang dijadikan titik tolak pengembangan model yang lebih lanjut dalam artian lebih rumit dan dalam artian lebih baru. 
Pelatihan adalah proses yang sistematis yang di lakukan secara berulang-ulang dan kian hari jumlah beban kian bertambah.di katakan sistematis dalam pengertian bahwa pelatihan dilaksanakan secara teratur, berencana, terprogram menurut jadwal berkesinambungan dari yang sederhana ke kompleks, dari yang mudah ke sulit, berulang-ulang berarti gerakan yang di pelajari harus dilatih secara berulang- ulang agar gerakan yang yang semula sukar dilakukan dan koordinasi gerakan yang sukar di lakukan menjadi kian mudah. Ada beberapa definisi yang di berikan oleh para ahli olahraga tentang makna dari pelatihan.

Kent dalam Budiwanto (2012:16) bahwa "latihan adalah suatu progam latihan fisik yang direncanakan untuk membantu mempelajari keterampilan, memperbaiki kesegaran jasmani, dan terutama untuk mempersiapkan atlet dalam suatu pertandingan". James Tangkudung dan wahyuningtas (2012:7) mengatakan "latihan merupakan proses yang berulang-ulang dan progresif guna meningkatkan potensi dalam rangka mencapai prestasi yang maksima"

Ruang lingkup cabang olahraga dayung canoeing itu sendiri terdiri dari berbagai jenis kegiatan olahraga, seperti yang diungkapkan yaitu Szanto (2014:28), "Canoeing disciplines belonging to the International Canoe Federation (ICF) are: Canoe Sprint, slalom racing, wildwater racing, marathon racing, canoe polo, canoe polo, dragonboat racing". Nomor canoeing dibagi menjadi dua nomor inti, yaitu canoe dan kayak. Perbedaan kedua nomor tersebut yaitu, pada nomor canoe biasanya pendayung menggunakan dayungan dengan satu daun dayung pada salah satu sisinya saja. Nomor kayak pendayung menggunakan dayungan dengan dua daun dayung pada kedua sisinya. Kejuaraan dayung banyak sekali nomer yang dipertandingkan diantaranya nomer kayak, kano Canadian, canoeing, dan perahu naga. Nomer kayak yang seing kali di pertandingkan yaitu nomer jarak 200 meter, 500 meter, dan jaraj 1000 meter sesuai dengan yang di pendapat szanto "In Canoe Sprint events, paddlers race on a straight course in lanes separated by markers over $200 \mathrm{~m} 500 \mathrm{~m}$ and 1,000 meter distances for both Canoe and Kayak".

Beberapa pola gerak atau perilaku yang diperluas bisa disebut keterampilan, misalnya berjalan, berlari, melompat. Kemampuan gerak merupakan suatu aktivitas yang sangat penting bagi manusia, karena dengan gerak manusia dapat meraih sesuatu yang menjadi harapannya. Konsep 
pembelajaran gerak merupakan dasar bagi pelaksanaan proses pembelajaran dan pelatihan gerak atau keterampilan gerak. Menurut Widiastuti (2011:165) kemampuan motorik merupakan sebagai suatu kapasitas dari seseorang yang berkaitan dengan pelaksanaan kemampuan fisik untuk dapat melaksanakan suatu gerakan, atau dapat pula didefinisikan bahwa kemampuan motorik adalah kapasitas penampilan seseorang dalam melakukan suatu gerak. Proses latihan erat kaitannya dengan belajar gerak. Belajar gerak (motor learning) adalah merupakan perubahan yang relatif permanen dalam kinerja atau berhubungan dengan perubahan perilaku gerak yang dihasilkan berkat latihan atau pengalaman di masa lalu.

Model pengembangan Borg and Gall terdiri dari 10 (sepuluh) tahapan, seperti tercantum pada gambar berikut:

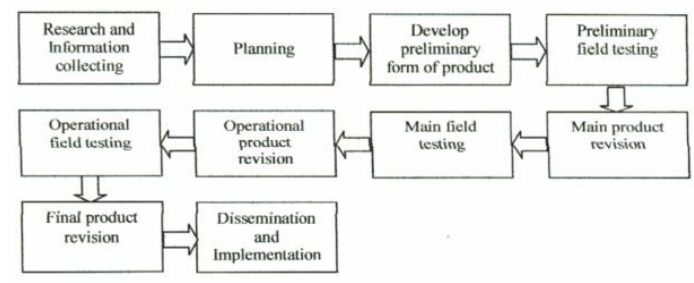

Sumber: Walter R. Borg and Meredith D. Gall, Educational Research: An Introduction, 4th Edition. (New York: Longman Inc., 1983)

Secara konseptual, pendekatan penelitian dan pengembangan mencakup 10 langkah umum, sebagaimana diuaraikan Borg and Gall sebagai berikut:

1) Research and information collecting, 2) Planning, 3) Develop preminary form of product, 4) Preliminary field testing, 5) Main product revision, 6) Main field testing, 7) Operational product revision, 8) Operational field testing, 9) Final product revision, dan 10) Dissemination and implementation.

Penelitian dan pengembangan (R\&D) merupakan menghasilkan produk baru yang akan dipakai dalam kegiatan melatih untuk mempermudah pelatih dalam memberikan dan menyampaikan materi latihan serta mempermudah pelatih untuk mencapai tujuan yang diharapkan. Penelitian pengembangan model latihan dayung berbasis modifikasi alat untuk atlet pemula secara khusus memilki beberapa tujuan diantaranya yaitu:

1. Mengembangkan dan menerapkan rancangan model latihan dayung berbasis modifikasi alat untuk atlet pemula pada cabang olahraga dayung. 
2. Memperoleh data empiris tentang efektivitas dan efisiensi hasil pengembangan model latihan dayung berbasis modifikasi alat untuk atlet pemula pada cabang olahraga dayung.

Tujuan akhir dari kegiatan penelitian dan pengembangan (R\&D) ini adalah untuk menghasilkan produk model latihan model latihan dayung berbasis modifikasi alat untuk atlet pemula pada cabang olahraga dayung yang dapat memberikan manfaat pada pelatih untuk mempermudah pelatih dalam menerapkan materi latihan. Sehingga nantinya dapat digunakan untuk meningkatkan kualitas dan akurasi teknik mendayung agar:

1. Efektif, artinya dengan latihan yang bervariatif dan berkualitas dapat meningkatkan kualitas mendayung dengan cepat.

2. Efisien, maksudnya dimana dengan biaya dan waktu yang minimal sehingga dapat diperoleh hasil yang maksimal dalam teknik dasar mendayung.

3. Menarik, artinya memiliki daya tarik sehingga atlet dapat termotivasi untuk memanfaatkannya

\section{METODELOGI PENELITIAN}

Penelitian pengembangan model latihan dayung berbasis alat sederhaanan ini menggunakan metode penelitian dan pengembangan atau Research and Development (R\&D)dari Borg dan Gall. Menurut Sugiyono (1013:297) metode penelitian dan pengembangan atau Research and Development (R\&D) adalah metode penelitian yang digunakan untuk menghasilkan produk tertentu, dan menguji keefektifan produk tersebut.

Penelitian ini menggunakan pendekatan kualitatif dan kuantitatif, yang merupakan pendekatan dengan tujuan menemukan jawaban dari masalah melalui rumusan masalah yang telah dirumuskan dalam bab I yaitu model dayung berbasis modifikasi alat untuk atlet pemula pada cabang olahraga dayung.

Penelitian dan pengembangan ini menggunakan pendekatan kualitatif dan kuantitatif serta menggunakan model pengembangan Research\& Development (R\&D) dari Borg dan Gall yang terdiri dari sepuluh langkah antara lain :

(1) Melakukan penelitian dan pengumpulan informasi (kajian pustaka, pengamatan subyek, persiapan laporan pokok persoalan) (2) Melakukan perencanaan (pendefinisian keterampilan, perumusan tujuan, penentuan urutan pengajaran, dan uji coba skala kecil) (3) Mengembangkan bentuk produk awal 
(penyiapan materi pengajaran, penyusunan buku pegangan, dan perlengkapan evaluasi) (4) Melakukan uji lapangan permulaan (menggunakan 6-12 subyek) (5) Melakukan revisi terhadap produk utama (sesuai dengan saran-saran dari hasil uji lapangan permulaan) (6) Melakukan uji lapangan utama (dengan 30-100 subyek). (7) Melakukan revisi produk (berdasarkan saran-saran dan hasil uji coba lapangan utama). (8) Uji lapangan dengan 40-200 subyek (9) Revisi produk akhir (10) Membuat laporan mengenai produk pada jurnal, bekerja dengan penerbit yang dapat melakukan distribusi secara komersial.

Penelitian ini dilaksanakan di UKM Dayung UPI (uji kelompok kecil), UKM MAHAPALA UBP (uji kelompok besar) dan UKM Dayung UNSIKA (uji efektifitas).

Waktu yang diperlukan dalam penelitian dan pengembangan ini mengacu pada penelitian riset dan pengembangan dari Borg and Gall yang direncanakan selama dua bulan setelah seminar proposal dan disetujui oleh dosen pembimbing, dengan rincian sebagai berikut :

a. Analisis Kebutuhan

b. Perencanaan pengembangan model

c. Pengembangan desain model latihan

d. Validasi para pakar dan revisi model latihan

e. Uji coba kelompok kecil dan revisi

f. Uji coba lapangan dan revisi

\section{HASIL PENELITIAN}

Analisis Model latihan dayung berbasis modifikasi alat untuk atlet pemula ini ditulis dalam bentuk naskah yang menyajikan bentuk-bentuk Model latihan dayung berbasis modifikasi alat untuk atlet pemula dalam bentuk latihan yang dimodifikasi dengan pendekatan model variasi latihan.

Analisis dilakukan untuk mengetahui seberapa penting model latihan yang akan dikembangkan. Peneliti melakukan penelitian awal atau analisis kebutuhan yang dilaksanakan pada tanggal 15 maret 2017, peneliti melakukan observasi menggunakan intrumen penilaian keterampilan mendayung kayak dan wawancara terhadap pelatih dayung mengenai model model latihan dayung di Unit Kegiatan Mahaatlet pemula (UKM). Dari hasil analisis kebutuhan tersebut dapat diketahui bahwa: (a) atlet mengalami kesulitan dalam latihan dayung, (b) pelatih menyatakan perlunya variasi model latihan dayung untuk dimasukan dalam proses latihan, khususnya saat latihan teknik. Paparan hasil penelitian 
awal analisis kebutuhan di atas maka dapat disimpulkan bahwa pentingnya variasi model latihan dayung berbasis modifikasi alat untuk atlet pemula.

Hasil studi pendahuluan atau temuan lapangan selanjutnya dideskripsikan dan dianalisis sehingga diperoleh suatu rumusan hasil data yang telah dikumpulkan. Rumusan hasil ini bersifat deskriptif dan analitis, dengan mengacu pada tujuan studi pendahuluan. Berikut akan dijabarkan mengenai hasil analisis kebutuhan dan temuan lapangan yang diperoleh peneliti.

Hasil analisis kebutuhan dan temuan dilapangan 1) proses latihan keterampilan dayung diberikan di ukm, 2) latihan keterampilan dayung dilakukan 2 kali dalam satu minggu 3) alat yang digunakan perahu, dayungan dan pelampung 4) proses latihan yang digunakan adalah atlet berlatih menggunakan perahu, dayungan, pelampung serta kurang koreksi dari pelatih karena jarak antara pelatih dan atlet cukup jauh, 5) atlet sangat antusisas karena atlet dapat mesakan berlatih di atas perahu. 6) belum pernah menggunakan model latihan dayung berbasis modifikasi alat. 7) pelatih menginginkan pengembangan model latihan dayung berbasis modifikasi alat.

Hasil studi pendahuluan atau temuan lapangan selanjutnya dideskripsikan dan dianalisis sehingga hasil ini bersifat deskriptif dan analitis, dengan mengacu pada tujuan studi pendahuluan. Berikut ini akan dijabarkan mengenai hasil analisis kebutuhan dan temuan lapangan yang diperoleh peneliti.

Hasil Tahap Pertama / Ujicoba Kelompok Kecil. Berdasarkan evaluasi uji coba kelompok kecil yang dilakukan oleh beberapa ahli dapat disimpulkan sebagai berikut :

1. Pada saat melakukan latihan dayung pelatih harus lebih banyak mengawasi karena untuk memberikan koreksi ketika atlet melakukan latihan tidak sesuai dengan petunjuk pelaksanaan.

2. Tingkat keamanan penggunaan alat dalam latihan dayung bagi pemula, dinyatakan sudah aman dan layak untuk digunakan.

3. Antusisme atlet pemula akan menggalami peningkatan jika latihan dayung diberikan berupa model-model yang bervariasi dan tidak mengurangi inti latihan itu sendiri.

4. Penggunaan alat-alat sederhana yang mudah didapat dinyatakan oleh para ahli sudah baik, 
5. Penyusunan model dari yang mudah ke jenjang yang lebih sulit, para ahli menyatakan sudah tersusun dengan baik.

6. Ahli menyatakan efetivitas penyusunan model latihan dayung bagi pemula dirasakan sudah efektif dalam membantu pelatih dayung dan pelatih UKM untuk mencapai tujuan prestasi khususnya latihan keterampilan mendayung kayak.

Hasil ujicoba kelompok kecil yang dilakukan terhadap 46 model latihan dayung bagi pemula yang dievaluasi oleh ahli, berdasarkan hasil analisis tiap-tiap model didapatkan model latihan kurang efektif dilakukan evaluasi kemudian diperbaiki dan digunakan untuk ujicoba kelompok besar.

Hasil Tahap Kedua/Uji Coba Kelompok Besar Setelah hasil model latihan dayung bagi pemula diuji cobakan dalam skala kecil dan telah direvisi, maka tahap selanjutnya adalah melakukan ujicoba kelompok besar (field group try out). Berdasarkan hasil ujicoba terbatas (ujicoba kelompok kecil) yang telah dievaluasi oleh para ahli, kemudian peneliti melakukan revisi produk awal dan memperoleh 36 model yang akan digunakan dalam ujicoba kelompok besar (field group try out).Langkah selanjutnya setelah model mengalami revisi tahap II dari ahli maka dilanjutkan dengan menguji cobakan produk pada kelompok besar (field group try out) dengan menggunakan penelitian sebanyak 5 atlet UKM TAPAK GIRI 20 atlet pemula MAHAPALA UBP dan 35 atlet pemula UKM Dayung unsika.

\section{PEMBAHASAN}

Berdasarkan hasil penelitian terdapat perbedaan antara hasil Pretest dan hasil Posttest yang diperoleh uji coba kelompok besar yang sebelumnya dilakukan Pretest atau tes awal dan Posttest yang dilakukan pada pemula, sebelum penerapan model-model latihan dayung bagi pemula diterapakan pada atlet pemula peneliti melakukan Pretest atau tes awal untuk mengetahui tingkat kemampuan dasar dayung yang dimiliki oleh subjek yang akan diteliti, hasil Pretest diperoleh jumlah hasil tingkat keterampilan dayung pemula 2158. Setelah itu treatment diberikan kepada atlet pemula dengan menggunakan model-model latihan dayung yang telah dikembangkan. Setelah treatment diberikan maka subjek di tes kembali dengan tes yang sama dengan tes keterampilan mendayung kayak sebelumnya tes ini dinamakan Posttest yang digunakan untuk mengetahui apakah terdapat peningkatan keterampilan dayung setelah pemberian treatment berupa model-model latihan dayung berbasis modifikasi 
alat pemula, maka diperoleh angka sebesar 3030. Berdasarkan keterangan tersebut dapat dikatakan bahwa model latihan dayung berbasis modifikasi alat untuk atlet pemula yang dikembangkan efektif dan meningkatkan keterampilan dayung nomer kayak untuk atlet pemula.

Produk yang dikembangkan ini bertujuan untuk membentuk meningkatkan tercapainya tujuan latihan dayung bagi pemula. Produk ini setelah dikaji mengenani beberapa kelemahan yang perlu pembenahan sesuai diatas maka dapat disampaikan beberapa keunggulan produk ini antara lain:

1. Atlet pemula lebih aktif dalam mengikuti proses latihan yang aman.

2. Atlet pemula terlihat gembira dan antusias karena bisa dilaksanakan dengan alat sederhana .

3. Model latihan dilakukan dari yang mudah ke yang sulit.

4. Tingkat kompetisi yang tinggi sehingga membuat atlet pemula lebih bersemangat.

5. Bisa dilaksanakan ditempat dan waktu yang diinginkan.

\section{KESIMPULAN}

Berdasarkan data yang diperoleh, dari hasil penelitian yang terdiri dari validasi ahli, uji coba kelompok kecil dan uji coba kelompok besar serta pembahasan dari hasil penelitian, maka peneliti dapat menarik kesimpulan bahwa :

1. Model latihan dayung berbasis modifikasi alat untuk atlet pemula dapat dikembangkan dan diterapkan dalam latihan pendidikan jasmani serta meningkatkan keterampilan dayung nomer kayak.

2. Model dayung yang telah dikembangkan, diperoleh data efektifitas dan hasil model latihan dayung berbasis modifikasi alat untuk atlet pemula.

Adapun saran-saran yang dikemukakan meliputi saran pemanfaatan, saran deseminasi, dan saran pengembangan lebih lanjut.

Produk pengembangan ini adalah materi dayung berbasis modifikasi alat untuk atlet pemula yang ditujukan pada mahasiswa yang dapat dipergunakan dalam kegiatan latihan Unit Kegiatan Mahasiswa (UKM). Dalam memanfaatkannya sangat perlu dipertimbangkan situasi, kondisi dan sarana prasarana.

Dalam penyebarluasan pengembangan kesasaran yang lebih luas, peneliti memberikan saran, antara lain: 
a. Sebelum disebarluaskan sebaiknya Model latihan dayung berbasis modifikasi alat untuk atlet pemula ini disusun kembali menjadi lebih baik, baik itu tentang kemasan maupun isi dari materi latihan dayung berbasis modifikasi alat untuk atlet pemula.

b. Agar Model latihan dayung berbasis modifikasi alat untuk atlet pemula ini dapat digunakan oleh pelatih dayung, maka sebaiknya dicetak lebih banyak lagi, sehingga nantinya para pelatih dapat mengetahui dengan baik

\section{SARAN}

Berdasarkan kesimpulan yang telah dikemukakan diatas, maka disarankan :

a. Untuk subyek penelitian sebaiknya dilakukan pada subyek yang lebih luas, baik itu atlet maupun UKM yang digunakan sebagai kelompok ujicoba.

b. Hasil pembuatan Model latihan dayung berbasis modifikasi alat untuk atlet pemula ini dapat disebarluaskan ke seluruh UKM dan Pengcap Dayung di Indonesia.

\section{DAFTAR PUSTAKA}

Bompa T, 1999. Periodezation training for sport: progam for peak strength in 35 sport. United States America: Human kinetic.

International Journal of Bio-Science and Bio-technology http://dx.doi.org/10.14257/ijbsbt.2014.6.5.23 (di akses 21 februari 2017)

Putra,nusa. 2012.Research \& Development .Jakarta:Raja Grafindo Persada

Sugiyono. 2011. Metode Penelitian Kuantitatif, Kualitatif dan R\&D Bandung: Alfabeta,

Setyo Budiwanto. 2012. Metodologi Latihan Olahraga Malang; UM Press

Szanto, Csaba.2014. Coaches education programe canoe sprint coaching manual level 2 and 3 Budapest

Szanto, Csaba. Racing Canoeing 2004. ICF International Canoeing Federation

Tangkudung, James. Wahyuningtyas Puspitarini, 2012. Kepelatihan Olahraga "Pembinaan Prestasi Olahraga" Edisi II, Jakarta :Penerbit Cerdas Jaya

Widiastuti, 2011.Tes dan Pengukuran Olahraga, Jakarta:Bintang Timur Jaya. 